\title{
A simple and rapid spectrophotometric method for the determination of iron in environmental, biological, pharmaceutical, food and soil samples using 1,2-dihydroxybenzene-3,5-disulfonic acid
}

\author{
Tasnima Zannat and Mohammed Jamaluddin Ahmed * \\ Laboratory of Analytical Chemistry, Department of Chemistry, University of Chittagong, Chittagong, 4331, Bangladesh \\ *Corresponding author at: Laboratory of Analytical Chemistry, Department of Chemistry, University of Chittagong, Chittagong, 4331, Bangladesh . \\ Tel.: +88.031.618236. Fax: +88.031.2606014. E-mail address: pmjahmed55@gmail.com (M.J. Ahmed).
}

\section{ARTICLE INFORMATION}

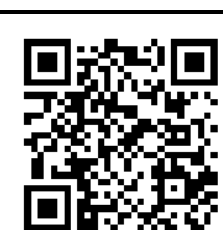

DOI: 10.5155 /eurjchem.5.1.101-110.882

\section{Received: 18 July 2013}

Received in revised form: 07 September 2013

Accepted: 07 September 2013

Online: 31 March 2014

\section{KEYWORDS}

Tiron

Biological samples

Iron determinatio

Spectrophotometry

Environmental samples

Pharmaceutical samples

\section{ABSTRACT}

An ultra-sensitive and highly selective non-extractive spectrophotometric method is presented for the rapid determination of iron (III) at trace levels using 1,2-dihydroxybenzene3,5 -disulfonic acid (Tiron) as a new spectrophotometric reagent $\left(\lambda_{\max }=665 \mathrm{~nm}\right)$ in slightly acidic aqueous $\left(2 \times 10^{-6}-2 \times 10^{-5} \mathrm{~mol} / \mathrm{L} \mathrm{H}_{2} \mathrm{SO}_{4}\right)$ solution. The reaction is instantaneous and absorbance remains stable for over $24 \mathrm{~h}$. The average molar absorption coefficient and Sandell's sensitivity and detection limit were found to be $6.0 \times 10^{5} \mathrm{~L} / \mathrm{mol} . \mathrm{cm}, 10 \mathrm{ng} / \mathrm{cm}^{2}$, and 1 $\mu \mathrm{g} / \mathrm{L}$, respectively. Linear calibration graphs were obtained for $0.02-70.00 \mathrm{mg} / \mathrm{L}$ of $\mathrm{Fe}(\mathrm{III})$. The stoichiometric composition of the chelate is 2:3 (Fe(III):Tiron). Large excesses of over 50 cations, anions and complexing agents (e.g. Tartrate, oxalate, citrate, phosphate, thiourea, and thiocyanate) do not interfere in the determination. The method was successfully used in the determination of iron in several standard reference materials (Alloys and steels) as well as in some environmental waters (portable and polluted), biological samples (Human blood and urine), food, pharmaceutical and soil samples, solution containing iron (II) and iron (III) and some complex synthetic mixtures. The method has high precision and accuracy $(s= \pm 0.01$ for $0.5 \mathrm{mg} / \mathrm{L}$ ).

\section{Introduction}

Iron plays a dual role in human biochemistry as in trace amounts, it is an essential nutrient, while large amounts are toxic and carcinogenic [1]. The essentiality and toxicity of iron depend on its oxidation states or the forms in which it was supplied. Iron in trace amounts is important industrially [2], as a biological nutrient [3], toxicant [4], environmental pollutant [5], and occupational hazards [6]. The industrial uses of iron and its compound are too numerous [7]. It is the major constituent in steel making. Several iron oxide form find use as paint pigments, polishing compounds, magnetic inks, and coatings for magnetic tapes. The soluble salts are variously used as dyeing mordant, catalysts, pigments, fertilizer, feeds, disinfectants, in tanning, soil conditioning, and treatment of sewage and industrial wastes [8]. Divalent iron is a cofactor in heme enzymes such as catalyses and cytochrome $\mathrm{C}$, and in nonheme enzymes such as aldolase and tryptophan oxygenase [7]. In human iron is an essential component involved in oxygen transport $[9,10]$. It is also essential for the regulation of cell growth and differentiation of iron limits oxygen delivery to cells [11], resulting in fatigue, poor work performance and decreased immunity [9]. On the other hand, excess amounts of iron can result in toxicity and even death [12]. Toxicology considerations are important in terms of iron deficiency (anemia) and accidental acute exposure and chronic iron overload due to idiopathic hemochromatosis or as a consequence of excess dietary iron or frequent blood transfusions. The immediate cause of death from the inorganic compounds of iron in animals is respiratory failure. Clinical signs preceding death are anorexia oligodipsia, oliguria, alkalosis, diarrhea, loss of body weight, hypothermia and alternating irritability and depression. In human poisonings, symptoms of iron intoxication include vomiting, cirrhosis of liver, hemochromatosis, diarrhea, lethargy, coma, irritability, seizures and abdominal pain [8]. All these findings cause great concern regarding public health, demanding accurate determination of this metal ion at trace and ultra-trace levels.

Spectrophotometry is one of the most powerful tools in chemical analysis. 1,2-dihydroxy-benzene-3,5-disulfonic acid (Tiron) (Scheme 1) has not previously been used for the spectrophotometric determination of iron. The method possesses distinct advantages over existing methods [13-18] with respect to sensitivity, selectivity, range of determination, simplicity, speed, $\mathrm{pH} /$ acidity range, thermal stability, accuracy, precision, and ease of operation. A comparison between existing methods [13-18] and the present method is shown in Table 1. 
Table 1. Summary of the existing spectrophotometric methods for the determination of iron.

\begin{tabular}{|c|c|c|c|c|c|c|}
\hline Reagent & $\begin{array}{l}\lambda \max \\
(\mathrm{nm})\end{array}$ & $\begin{array}{l}\varepsilon \\
\text { (L/mol.cm) }\end{array}$ & $\begin{array}{l}\text { Beer's law } \\
(\mathrm{mg} / \mathrm{L})\end{array}$ & Interference & Remarks & Reference \\
\hline 1-Nitroso-2-naphtol & 420 & $2.57 \times 10^{4}$ & $0.05-3.5$ & Many & $\begin{array}{l}\text { i) } \mathrm{pH} \text { dependent } \\
\text { ii) Less sensitive } \\
\text { iii)Less selective due to } \\
\text { much interference }\end{array}$ & [13] \\
\hline 2,2-Dipyridine & 522 & $8.7 \times 10^{3}$ & $0.1-50$ & Many & $\begin{array}{l}\text { i) } \mathrm{pH} \text { - dependent } \\
\text { ii) Less selective due to } \\
\text { much interference } \\
\text { iii) Less sensitive }\end{array}$ & [14] \\
\hline Dimethyldithi-ocarbamate & 426 & $1.6 \times 10^{3}$ & $0.5-20$ & Many & $\begin{array}{l}\text { i) Solvent extractive } \\
\text { ii) Less selective due to } \\
\text { much interference } \\
\text { iii) Lengthy and time } \\
\text { consuming }\end{array}$ & [15] \\
\hline Ferrozine & 560 & $4 \times 10^{4}$ & $0-10$ & $\begin{array}{l}\text { Co(II), Zn, Mn, Cd, } \\
\text { Pb etc. }\end{array}$ & $\begin{array}{l}\text { i) Less selective due to } \\
\text { much interference } \\
\text { ii) Solvent extractive } \\
\text { iii) Less sensitive }\end{array}$ & [16] \\
\hline $\begin{array}{l}\text { 5-Nitro-6-amino-1, 10-phenanthrolone } \\
\text { (NAP) }\end{array}$ & 520 & $1.39 \times 10^{3}$ & $1-4$ & $\begin{array}{l}\mathrm{Cu}(\mathrm{II}) \\
\mathrm{Ni}(\mathrm{II}) \\
\mathrm{Co}(\mathrm{II}), \mathrm{Zn}, \\
\mathrm{Mn}, \mathrm{Al}, \mathrm{Ca}, \mathrm{Mg}\end{array}$ & $\begin{array}{l}\text { i) Temperature dependent } \\
\text { ii) pH dependent } \\
\text { ii) Less selective due to } \\
\text { much interference } \\
\text { iv)Less sensitive }\end{array}$ & [17] \\
\hline $\begin{array}{l}\text { 1,2-Dihadroxy-3,4 diketocyclobutence } \\
\text { (squaric acid) }\end{array}$ & 515 & $3.95 \times 10^{3}$ & $0.5-20$ & Many & $\begin{array}{l}\text { i) pH dependent } \\
\text { ii) Less sensitive } \\
\text { iii) Solvent extractive } \\
\text { iv) Less selective due to } \\
\text { much interference } \\
\text { v)Lengthy and time } \\
\text { consuming }\end{array}$ & [18] \\
\hline $\begin{array}{l}\text { Tiron }[1,2 \text {-Dihydroxybenzene-3,5- } \\
\text { disulfonic acid(disodium salt hydrate) } \\
\text { (Present method) }\end{array}$ & 665 & $6 \times 10^{5}$ & $0.02-70$ & $\begin{array}{l}\text { Using suitable } \\
\text { masking agents, } \\
\text { the reaction can be } \\
\text { made highly selective }\end{array}$ & $\begin{array}{l}\text { i) Non-extractive and very } \\
\text { simple } \\
\text { ii)Highly sensitive } \\
\text { iii)Highly selective } \\
\text { iv) Aqueous reaction } \\
\text { media } \\
\text { v) Simple and rapid } \\
\text { method }\end{array}$ & $\begin{array}{l}\text { Present } \\
\text { Method }\end{array}$ \\
\hline
\end{tabular}<smiles>[NH3+]OS(=O)(=O)c1cc(S(=O)(=O)[O-])cc(O)c1O</smiles>

1,2-Dihydroxybenzene-3,5-disulfonic acid (Disodium salt hydrate) (Tiron)

Scheme 1

The method is based on the reaction of non-absorbent tiron in a slightly acidic solution $\left(2 \times 10^{-6}-2 \times 10^{-5} \mathrm{~mol} / \mathrm{L} \mathrm{H}_{2} \mathrm{SO}_{4}\right)$ with iron(III) to produce a highly absorbent navy-blue chelate product followed by a direct measurement of the absorbent in an aqueous solution. With suitable masking, the reaction can be made highly selective and the reagent blank solutions do not show any absorbance.

\section{Experimental}

\subsection{Apparatus}

A Shimadzu (Kyoto, Japan) (Model - 1800) double beam UV/VIS the recording spectrophotometer and a Jenway (England UK) (Model - 3010) pH-meter with a combination of electrodes were used for the measurements of absorbance and $\mathrm{pH}$, respectively. A Shimadzu (Model: AA7000) atomic absorption spectrometer equipped with a microcomputercontrolled air-acetylene flame was used for comparison of the results.

\subsection{Reagents and solutions}

All chemicals used were of analytical-reagent grade or the highest purity available. Doubly distilled deionized water was used throughout this study. Glass vessels were cleaned by soaking in acidified solutions of $\mathrm{KMnO}_{4}$ or $\mathrm{K}_{2} \mathrm{Cr}_{2} \mathrm{O}_{7}$, followed by washing with concentrated $\mathrm{HNO}_{3}$, and was rinsed several times with high-purity deionized water. Stock solutions and environmental water samples ( $1000 \mathrm{~mL}$ each) were kept in polypropylene bottles containing $1 \mathrm{~mL}$ of concentrated $\mathrm{HNO}_{3}$. More rigorous contamination control was applied when the iron levels in specimens were low.

\subsubsection{Tiron solution}

Tiron solution $\left(3 \times 10^{-3} \mathrm{~mol} / \mathrm{L}\right)$ was prepared by dissolving the requisite amount of tiron (BDH Chemicals, purity $>99 \%$ ) in a known volume of doubly distilled deionized water. More dilute solutions of the reagent were prepared as and when required.

\subsubsection{Iron (II) standard solution}

A $100 \mathrm{~mL}$ amount of stock solution $(1 \mathrm{mg} / \mathrm{mL})$ of divalent iron was prepared by dissolving $497 \mathrm{mg}$ of purified-grade 
(Merck pro analysis grade) $\mathrm{FeSO}_{4} .7 \mathrm{H}_{2} \mathrm{O}$ in deionized water. More dilute standard solutions were prepared by appropriate dilution of aliquots from the stock solution with deionized water as and when required. Concentrations $\left(1.79 \times 10^{-2} \mathrm{~mol} / \mathrm{L}\right)$ were checked using the standard potassium dichromate solution [19].

\subsubsection{Iron (III) standard solution}

A $100 \mathrm{~mL}$ amount of stock solution $(1 \mathrm{mg} / \mathrm{mL})$ of trivalent iron was prepared by dissolving $490 \mathrm{mg}$ of ferric chloride $\left(\mathrm{FeCl}_{3} .6 \mathrm{H}_{2} \mathrm{O}\right)$ (Aldrich A.C.S. grade) in doubly distilled deionized water. Aliquots of this solution were standardized with potassium dichromate solution [19]. More dilute standard solutions $\left(1.79 \times 10^{-2} \mathrm{~mol} / \mathrm{L}\right)$ were prepared from this stock solution as and when required.

\subsubsection{Potassium permanganate solution}

A $1 \%$ potassium permanganate (Merck) solution was prepared by dissolving in deionized water. Aliquots of this solution were standardized with oxalic acid.

\subsubsection{Potassium dichromate solution}

A $100 \mathrm{~mL}$ amount of stock solution $(0.1 \mathrm{~N})$ was prepared by dissolving $500 \mathrm{mg}$ of finely powdered $\mathrm{K}_{2} \mathrm{Cr}_{2} \mathrm{O}_{7}$ (Merck) in 100 $\mathrm{mL}$ deionized water.

\subsubsection{Sodium azide solution}

Sodium azide solution $(2.5 \%$ w:v) (Fluka purity $>99 \%)$ was freshly prepared by dissolving $2.5 \mathrm{~g}$ in $100 \mathrm{~mL}$ of deionized water.

\subsubsection{Tartrate solution}

A $100 \mathrm{~mL}$ stock solution of tartrate $(0.01 \%$ w:v) was prepared by dissolving $10 \mathrm{mg}$ of potassium sodium tartrate tetra hydrate (ACS-grade, 99\%) in $100 \mathrm{~mL}$ deionized water.

\subsubsection{Aqueous ammonium solution}

A $100 \mathrm{~mL}$ solution of aqueous ammonia was prepared by diluting $10 \mathrm{~mL}$ concentrated $\mathrm{NH}_{4} \mathrm{OH}(28-30 \%$, ACS grade) to $100 \mathrm{~mL}$ with deionized water. The solution was stored in a polypropylene bottle.

\subsubsection{EDTA solution}

A $100 \mathrm{~mL}$ stock solution of EDTA $(0.01 \%$ w:v) was prepared by dissolving $10 \mathrm{mg}$ ethylenediaminetetraacetic acid (A.C.S.-grade, $\geq 99 \%$ ) as disodium salt dihydrate in $100 \mathrm{~mL}$ deionized water.

\subsubsection{Other solutions}

Solutions of a large number of inorganic ions and complexing agents were prepared from their analytical grade or equivalent grade water soluble salts (or the oxides and carbonates in hydrochloric acid); those of niobium, tantalum, titanium, zirconium and hafnium were specially prepared from their corresponding oxides (Specupure, Johnson Matthey) according to the recommended procedures of Mukharji [20]. In the case of insoluble substances, special dissolution methods were adopted [21].

\subsection{Procedure}

A volume of $0.1-1.0 \mathrm{~mL}$ of a neutral aqueous solution containing $0.2-700 \mu \mathrm{g}$ of iron(III) in a $10 \mathrm{~mL}$ calibrated flask was mixed with a 1:75-1:350 fold molar excess of the tiron reagent solution (preferably $2 \mathrm{~mL}$ of $3 \times 10^{-3} \mathrm{~mol} / \mathrm{L}$ ) followed by the addition of $0.2-2.0 \mathrm{~mL}$ (preferably $1 \mathrm{~mL}$ ) of $1 \times 10^{-4} \mathrm{~mol} / \mathrm{L}$ sulfuric acid. After one minute the mixture was diluted to the mark with deionized water. The absorbance was measured at $665 \mathrm{~nm}$ against a corresponding reagent blank. The iron content in an unknown sample was determined using a concurrently prepared calibration graph.

\subsection{Sample collection and preservation}

Water: Water samples were collected in polythene bottles from shallow tube-wells, tap-wells, river, sea and drain of different places of Bangladesh. After collection, $\mathrm{HNO}_{3}(1 \mathrm{~mol} / \mathrm{L})$ was added as preservative.

Blood and urine: Blood and urine samples were collected in polypropylene bottles from effected persons of Chittagong Medical College Hospital, Bangladesh. Immediately after collection they were stored in a salt-ice mixture and latter, at the laboratory, were kept at $-20^{\circ} \mathrm{C}$.

Soil: Soil (surface) samples were collected from different locations in Bangladesh. Samples were dried in air and homogenized with a mortar.

Food: Food samples were collected from local market of Chittagong in Bangladesh.

\section{Results and discussions}

\subsection{Absorption spectra}

The absorption spectra of the Fe(III)-tiron system in $1 \times 10^{-4}$ $\mathrm{mol} / \mathrm{L} \mathrm{H}_{2} \mathrm{SO}_{4}$ medium were recorded using the spectrophotometer. The absorption spectra of the Fe(III)-tiron is a symmetric curve with maximum absorbance at $665 \mathrm{~nm}$ and the average molar absorption coefficient of $6 \times 10^{5} \mathrm{~L} / \mathrm{mol} . \mathrm{cm}$ was shown in Figure 1. The reagent blank exhibited negligible absorbance despite having wave length in the same region. The reaction mechanism of the present method is as reported earlier [22].

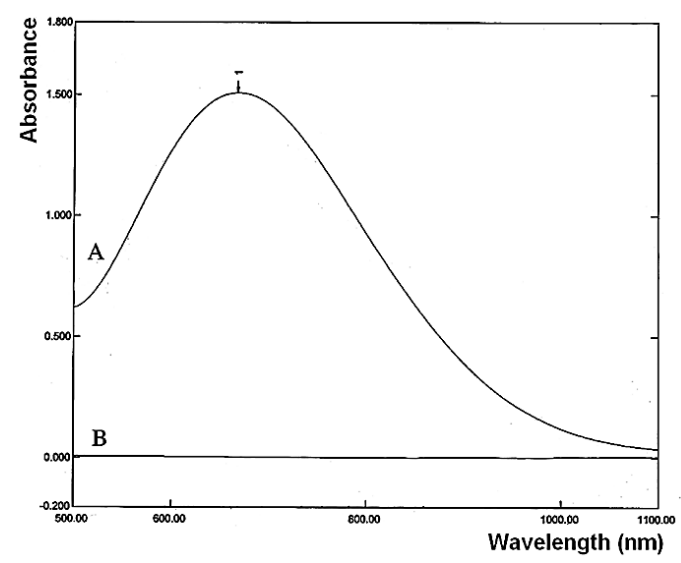

Figure 1. A and B Absorbance spectra of Fe(III)-Tiron system and the reagent blank $\left(\lambda_{\max }=665 \mathrm{~nm}\right)$ in aqueous solutions, respectively.

\subsection{Effect of acidity}

Of the various acids (nitric, hydrochloric, sulfuric and phosphoric) studied. Sulfuric acid was found to be the best acid for the system. The absorbance was maximum and constant when the $10 \mathrm{~mL}$ of solution $(1 \mathrm{mg} / \mathrm{L})$ contained $0.2-2.0 \mathrm{~mL}$ of $1 \times 10^{-4} \mathrm{M} \mathrm{H}_{2} \mathrm{SO}_{4}$ at room temperature. Outside this range of acidity, the absorbance decreased (Figure 2). For all subsequent measurements, $1 \mathrm{~mL}$ of $1 \times 10^{-4} \mathrm{M} \mathrm{H}_{2} \mathrm{SO}_{4}$ was added. 
Table 2. Selected analytical parameters obtained with the optimization experiments.

\begin{tabular}{lll}
\hline Parameters & Studied range & Selected value \\
\hline Wavelength, $\lambda_{\max }(\mathrm{nm})$ & $200-800$ & 665 \\
Acidity $\left(\mathrm{M} \mathrm{H}_{2} \mathrm{SO}_{4}\right)$ & $1 \times 10^{-7-3 \times 10^{-5}}$ & $2 \times 10^{-6}-2 \times 10^{-5}\left(\mathrm{preferably,} 1 \times 10^{-4}\right)$ \\
$\mathrm{pH}$ & $4.58-3.76$ & $4.5-5.5(\mathrm{preferably,5.00)}$ \\
Time $(\mathrm{h})$ & $0-72$ & $1 \mathrm{~min}-24 \mathrm{~h}(\mathrm{preferably,} 1 \mathrm{~min})$ \\
Temperature $\left({ }^{\circ} \mathrm{C}\right)$ & $10-90$ & $25 \pm 5$ \\
Reagent $($ fold molar excess, $\mathrm{M}: \mathrm{R})$ & $1: 1-1: 350$ & $1: 75-1: 350$ (preferably, $1: 75)$ \\
Molar absorptivity $(\mathrm{L} / \mathrm{mol} . \mathrm{cm})$ & $5.25 \times 10^{5}-6.75 \times 10^{5}$ & $6 \times 10^{5}$ \\
Linear range $(\mathrm{mg} / \mathrm{L})$ & $0.001-100$ & $0.02-70$ \\
Detection limit $(\mu \mathrm{g} / \mathrm{L})$ & $0.01-100$ & 1.0 \\
Sandell's sensitivity $\left(\mathrm{ng} / \mathrm{cm}^{2}\right)$ & $1-100$ & 10 \\
Reproducibility $(\% \mathrm{RSD})$ & $0-5$ & $0-3$ \\
Regression co-efficient $\left(\mathrm{R}^{2}\right)$ & $0.9996-0.9998$ & 0.9997 \\
\hline
\end{tabular}

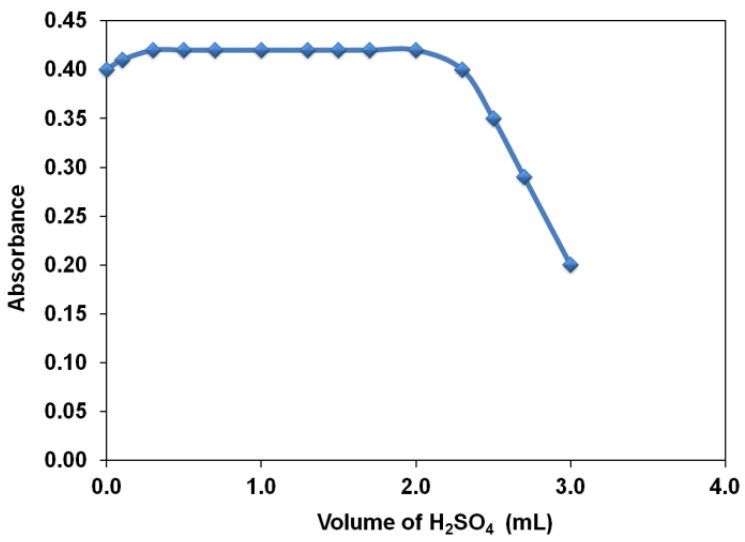

Figure 2. Effect of acidity on the absorbance of Fe(III)-Tiron system $(0.0001$ $\mathrm{M} \mathrm{H}_{2} \mathrm{SO}_{4}$ )

\subsection{Effect of time}

The reaction was very fast. Constant maximum absorbance was obtained within few seconds after the dilution to volume and remained strictly unaltered for over 24 hours. A longer period of time was not studied.

\subsection{Effect of temperature}

Effect of various temperatures $\left(10-90{ }^{\circ} \mathrm{C}\right)$ on $\mathrm{Fe}(\mathrm{III})$-tiron system was studied. The iron(III)-tiron system attained maximum and constant absorbance at room temperature $\left(25 \pm 5^{\circ} \mathrm{C}\right)$.

\subsection{Effect of reagent concentration}

Different molar excesses of tiron were added to a fixed metal ion concentration and absorbances were measured according to the standard procedure. It was observed that at 1 $\mathrm{mg} / \mathrm{L} \mathrm{Fe}(\mathrm{III})$ metal, the reagent molar ratios of 1:75-1:350 produced a constant absorbance of the Fe-chelate (Figure 3). For all subsequent measurements, $2 \mathrm{~mL}$ of $3 \times 10^{-3} \mathrm{M}$ tiron reagent was added.

\subsection{Effect of metal concentration (Beer's law)}

The well-known equation for spectrophotometric analysis in very dilute solutions derived from Beer's law. The effect of metal concentration was studied over $0.01-100 \mathrm{mg} / \mathrm{L}$ distributed in four different sets (0.01- 0.10, 0.1-1.0, 1-10 and $10-100 \mathrm{mg} / \mathrm{L}$ ) for convenience of measurement. The absorbance was linear for $0.02-70.00 \mathrm{mg} / \mathrm{L}$ of Fe(III) at 665 $\mathrm{nm}$. The molar absorption coefficient and Sandell's sensitivity [23] were $6 \times 10^{5} \mathrm{~L} / \mathrm{mol} . \mathrm{cm}$ and $10 \mathrm{ng} / \mathrm{cm}^{2}$, respectively. Of the four calibration curves, the first three pass through the origin and the fourth (Figure 4) one shows the deviation from linearity. The selected analytical parameters obtained with the optimization experiments are summarized in Table 2.

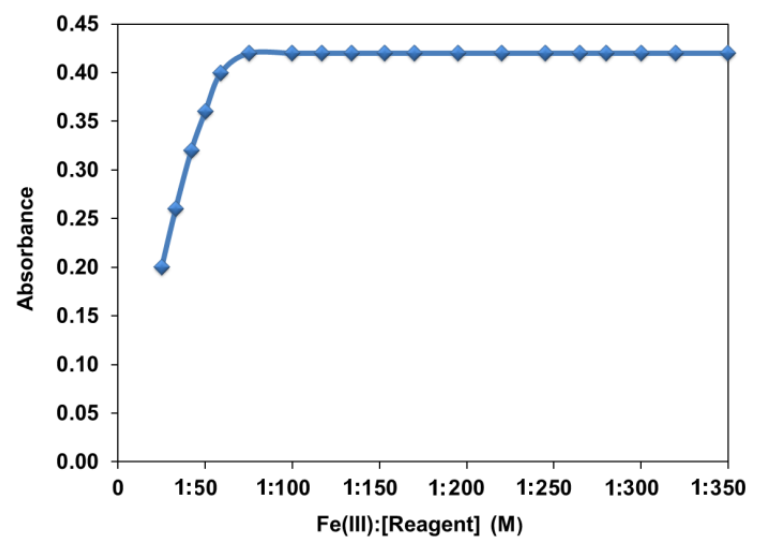

Figure 3. Effect of reagent (Fe(III):Tiron molar concentration ratio) on the absorbance of Fe(III)-Tiron system.

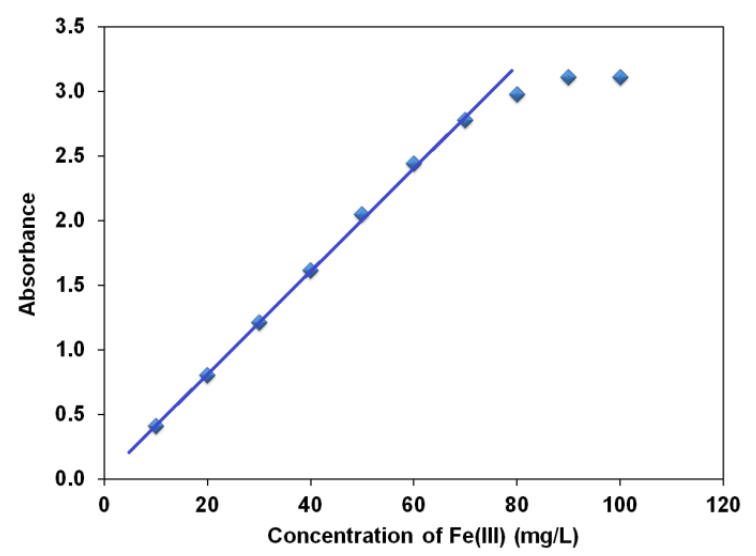

Figure 4. Calibration graph-D, $10-70 \mathrm{mg} / \mathrm{L}$ of iron(III).

\subsection{Effect of foreign ions}

The effect of over 50 anions, cations, and complexing agents on the determination of only $1 \mathrm{mg} / \mathrm{L}$ of Fe(III) was studied. The criterion for interference [24] was an absorbance value varying by more than $5 \%$ from the expected value for Fe(III) alone. The results are summarized in Table 3 . As can be seen, a large number of ions have no significant effect on the determination of iron. Only iron(II) interferes and in order to eliminate this interference 1,10-phenanthroline is used as masking agents. During the interference studies, if a precipitate was formed, it was removed by centrifugation. 
Table 3. Tolerance limits a of foreign ions, tolerance ratio[Species (x)/Fe $(w: w)]$.

\begin{tabular}{|c|c|c|c|}
\hline Species, $x$ & Tolerance ratio, [Species (x)/Fe $(w: w)]$ & Species, $\mathrm{x}$ & Tolerance ratio, [Species (x)/Fe (w:w)] \\
\hline Acetate & 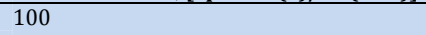 & Lead(II) & 100 \\
\hline Aluminum & 100 & Magnesium & 100 \\
\hline Ammonium & 1000 & Manganese(II) & 1000 \\
\hline Arsenic(III) & 50 & Manganese(VII) & 100 \\
\hline Arsenic (V) & 500 & Mercury(II) & 100 \\
\hline Ascorbic acid & 500 & Molybdenum(VI) & 50 \\
\hline Antimony & 50 & Nickel(II) & 500 \\
\hline Azide & 100 & Nitrate & 1000 \\
\hline Barium & 100 & Oxalate & 20 \\
\hline Beryllium(II) & 100 & Phosphate & 1000 \\
\hline Bromide & 1000 & Potassium & 1000 \\
\hline Phosphate & 100 & Selenium(IV) & 25 \\
\hline Cadmium & 100 & Selenium(VI) & 1000 \\
\hline Calcium & 200 & Silver & 100 \\
\hline Cesium & 1000 & Sodium & 50 \\
\hline Chloride & 1000 & Strontium & 100 \\
\hline Chromium(III) & 100 & Tartrate & 100 \\
\hline Chromium(VI) & 100 & Tellurium & 500 \\
\hline Citric acid & 50 & Thiocyanate & 10 \\
\hline Copper (II) & 100 & Tin(II) & 50 \\
\hline Cyanide & 1000 & Tin(IV) & 100 \\
\hline Carbonate & 50 & Titanium(IIII) & 100 \\
\hline Cerium(III) & 100 & Tungsten(VI) & 100 \\
\hline EDTA & 10 & Vanadium(V) & 50 \\
\hline Fluoride & 1000 & Zinc & 100 \\
\hline Iron(II) & $50 \mathrm{~b}$ & Lithium & 100 \\
\hline Iodide & 1000 & Nitrite & 1000 \\
\hline
\end{tabular}

a Tolerance limit was defined as ration that causes less than \pm 5 percent interference.

b With 1,10-phenanthroline.

Table 4. Determination of iron in some synthetic mixtures.

\begin{tabular}{|c|c|c|c|c|}
\hline \multirow[t]{2}{*}{ Sample } & \multirow[t]{2}{*}{ Composition of mixtures(mg/L) } & \multicolumn{3}{|c|}{ Iron(III) (mg/L) } \\
\hline & & Added & Found a & Recovery $\pm \mathrm{s}^{\mathrm{b}}(\%)$ \\
\hline \multirow[t]{2}{*}{$\bar{A}$} & $\mathrm{Fe}^{3+}$ & 0.50 & 0.49 & $98 \pm 1.0$ \\
\hline & & 1.00 & 1.00 & $100 \pm 0.0$ \\
\hline \multirow[t]{2}{*}{ B } & As in $\mathrm{A}+\mathrm{Cu}^{2+}(50)+\mathrm{Ca}(50)$ & 0.50 & 0.50 & $100 \pm 0.0$ \\
\hline & & 1.00 & 0.99 & $99 \pm 1.0$ \\
\hline \multirow[t]{2}{*}{$\mathrm{C}$} & As in $\mathrm{B}+\mathrm{Mn}^{2+}(25)+\mathrm{Ni}^{2+}(25)$ & 0.50 & 0.49 & $98 \pm 1.0$ \\
\hline & & 1.00 & 1.02 & $102 \pm 1.0$ \\
\hline \multirow[t]{2}{*}{ D } & As in $\mathrm{C}+\mathrm{K}(25)+\mathrm{Co}^{2+}(25)+\mathrm{Hg}^{2+}(25)$ & 0.50 & 0.52 & $104 \pm 1.3$ \\
\hline & & 1.00 & 1.03 & $103 \pm 1.0$ \\
\hline \multirow[t]{2}{*}{ E } & As in $\mathrm{D}+\mathrm{Zn}(25)+\mathrm{Pb}^{2+}(25)+\mathrm{Cd}(25)$ & 0.50 & 0.54 & $108 \pm 1.0$ \\
\hline & & 1.00 & 1.08 & $108 \pm 1.2$ \\
\hline \multirow[t]{2}{*}{$\mathrm{F}$} & As in $\mathrm{E}+\mathrm{Mg}(25)+\mathrm{Al}(25)+\mathrm{Sr}(25)$ & 0.50 & 0.55 & $110 \pm 1.8$ \\
\hline & & 1.00 & 1.10 & $110 \pm 1.5$ \\
\hline
\end{tabular}

a Average of five analysis of each sample.

$\mathrm{b}$ The measure of precision is the standard deviation (s).

The amount mentioned is not the tolerance limit but the actual amount studied. However, for those ions whose tolerance limit has been studied, their tolerance ratios are given in Table 3.

\subsection{Composition of the absorbent complex}

Job's method [25] of continuous variation and the molar ratio [26] method were applied to ascertain the stoichiometric composition of the complex (Figure 5). A Fe-tiron complex was indicated by both methods.

\subsection{Precision and accuracy}

The precision of the present method was evaluated by determining different concentrations of iron (each analyzed at least five times). The relative standard deviation $(n=5)$ was 0 $3 \%$ for $0.2-700.0 \mu \mathrm{g}$ of iron(III) in $10 \mathrm{~mL}$, indicating that this method is highly precise and reproducible.

The detection limit (3s/S of the blank) and Sandell's sensitivity (concentration for 0.001 absorbance unit) for iron(III) were found to be $1 \mu \mathrm{g} / \mathrm{L}$ and $10 \mathrm{ng} / \mathrm{cm}^{2}$, respectively. The method was tested by analyzing several synthetic mixtures containing iron(III) and diverse ions (Table 4). The results for total iron were in good agreement with certified values (Table 5). The reliability of our Fe-chelate procedure was also tested by recovery studies. The average percentage recovery obtained for addition of iron(III) spike to some environmental water samples was quantitative as shown in (Table 6) The results of biological analyses by the spectrophotometric method were in excellent agreement with those obtained by AAS (Table 7).

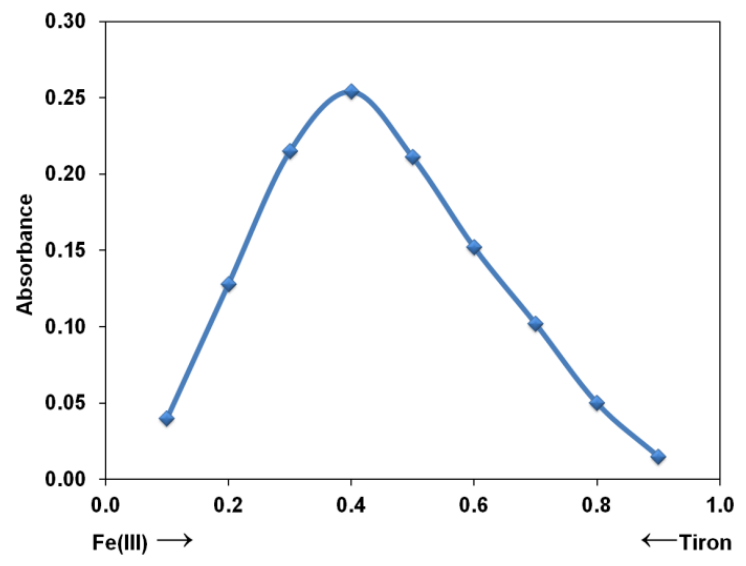

Figure 5. Composition of Fe(III)-Tiron complex by the Job's method. 
Table 5. Determination of iron in certified reference materials.

\begin{tabular}{|c|c|c|c|c|}
\hline \multirow[t]{2}{*}{ Sample no } & \multirow[t]{2}{*}{ Certified reference materials (Composition, \%) } & \multicolumn{2}{|l|}{ Iron (\%) } & \multirow{2}{*}{$\begin{array}{l}\text { RSD } \\
(\%)\end{array}$} \\
\hline & & Certified value & Found a & \\
\hline 1 & $\begin{array}{l}\text { BAS-CRM-20 b; High speed Steel } \\
(\mathrm{Al}=90.5, \mathrm{Fe}=0.43, \mathrm{Cu}=4.1, \mathrm{Ni}=1.9, \mathrm{Mn}=0.19, \mathrm{Si}=0.24\end{array}$ & 0.43 & 0.45 & 2.5 \\
\hline 2 & $\begin{array}{l}\text { YSBC } 19716 \mathrm{c} \text { High tensile steel } \\
(\mathrm{Fe}=34.26, \mathrm{Zn}=36.24, \mathrm{Si}=0.38, \mathrm{Cd}=1.2, \mathrm{Sb}=48.57, \mathrm{~S}=0.95 \text { and } \mathrm{F}=0.32)\end{array}$ & 1.56 & 1.52 & 1.5 \\
\hline 3 & $\begin{array}{l}\text { YSBC } 19716^{c} \text { High tensile steel } \\
(\mathrm{Fe}=34.26, \mathrm{Zn}=36.24, \mathrm{Si}=0.38, \mathrm{Cd}=1.2, \mathrm{Sb}=48.57, \mathrm{~S}=0.95 \text { and } \mathrm{F}=0.32)\end{array}$ & 34.46 & 34.12 & 1.0 \\
\hline 4 & $\begin{array}{l}\text { BY 0110 } 1 \text { c High tensile steel } \\
(\mathrm{Zn}=42.98, \mathrm{Si}=19.89, \mathrm{Fe}=4.13, \mathrm{~Pb}=0.351, \mathrm{Sn}=0.06, \mathrm{Cd}=0.04, \mathrm{As}=0.024, \mathrm{Sn}=0.06 \text { and } \mathrm{Cu}=14)\end{array}$ & 4.13 & 4.06 & 1.4 \\
\hline 5 & $\begin{array}{l}\text { GSBD 33001-94 c High tensile steel } \\
(\mathrm{Fe}=9.53, \mathrm{Si}=14.64, \mathrm{Al}=9.29, \mathrm{Ca}=1.04, \mathrm{Mg}=21.49 \text { and } \mathrm{Cr}=32.79)\end{array}$ & 9.53 & 9.38 & 1.2 \\
\hline
\end{tabular}

a Average of five replicate determinations.

${ }^{\mathrm{b}}$ The measure of precision is the relative standard deviation (RSD).

c These CRMs were obtained from Beijing NCS Analytical Instruments Co. Ltd, China.

Table 6. Determination of iron in some environmental water samples.

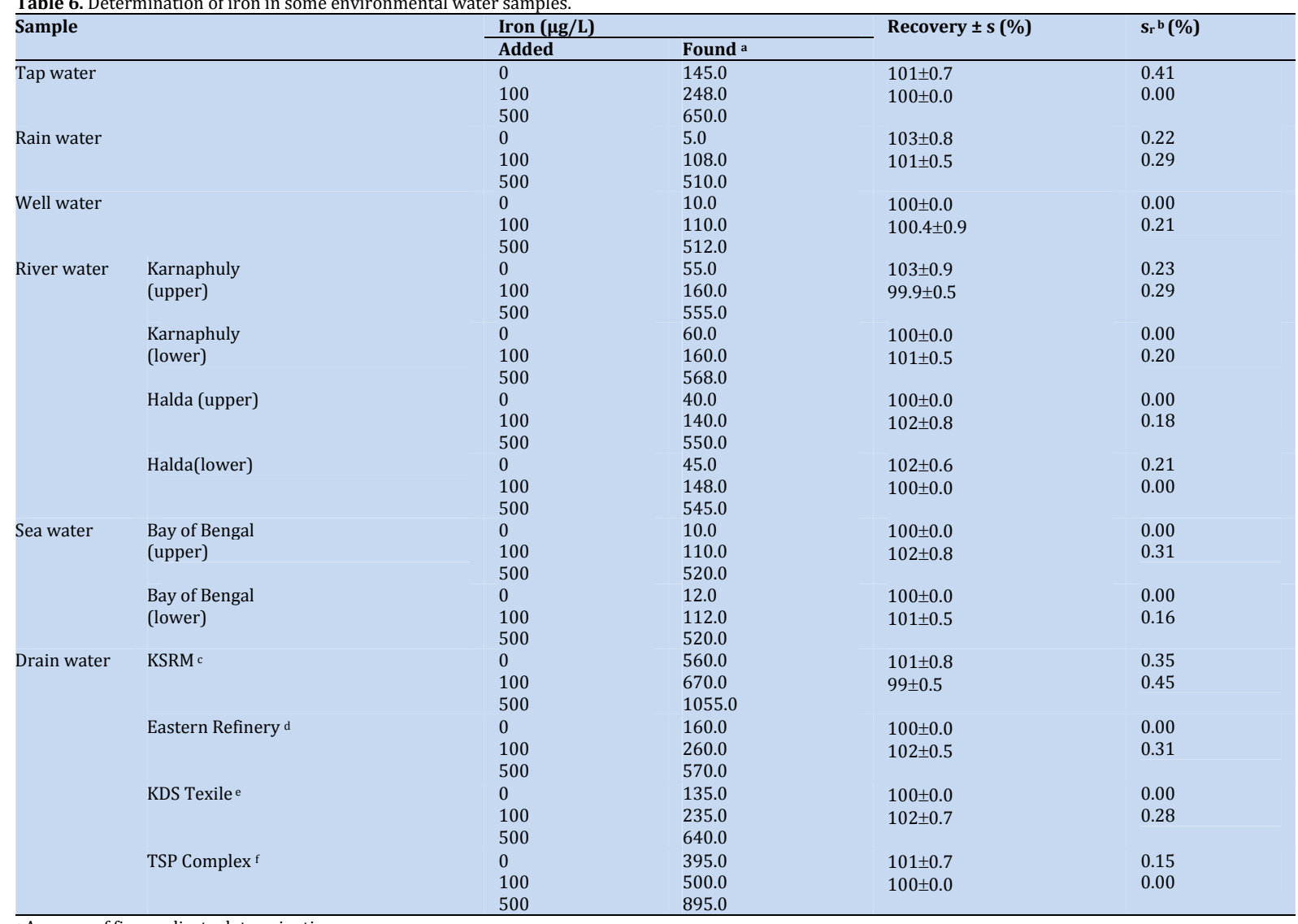

average of five replicate determinations.

${ }^{b}$ The measure of precision is the relative standard deviation ( $\mathrm{sr}_{\mathrm{r}}$ ).

c Kabir Steel Re-Rolling Mills, Chittagong.

d Estern Refinary Ltd., Patenga, Chittagong.

e KDS Textile Ltd., Oxygen, Chittagong.

f TSP complex Ltd., Patenga, Chittagong.

\subsection{Applications}

The proposed method was successfully applied to the determination of iron(III) in a series of synthetic mixtures of various compositions (Table 4) and also in a number of real samples e.g. several Certified Reference Materials (CRMs) (Table 5). The method was also extended to the determination of iron in a number of environmental, biological, pharmaceutical, soil and food samples. In view of the unknown composition of environmental water samples, the same equivalent portions of each such samples were analyzed for iron content; the recoveries in both the "spiked" (added to the samples before the mineralization or dissolution) and the "unspiked" samples are in good agreement (Table 6). The results of biological analyses by spectrophotometric method were found to be in excellent agreement with those obtained by AAS (Table 7). The results of soil sample analyzed by the spectrophotometric method are shown in Table 8. The results of food and pharmaceutical samples by the spectrophotometric method are shown in Table 9 and 10. The results of speciation of iron(II) and iron(III) in mixtures are shown in Table 11. The results of speciation of iron(II) and iron(III) in mixtures were highly reproducible (Table 11). Hence, the precision and accuracy of the method were excellent 
Table 7. Concentration of iron in blood and urine samples.

\begin{tabular}{|c|c|c|c|c|c|c|}
\hline \multirow[t]{3}{*}{ Serial no } & \multirow[t]{3}{*}{ Sample } & \multicolumn{4}{|c|}{ Iron $(\mathrm{mg} / \mathrm{L})$} & \multirow[t]{3}{*}{ Sample source $^{a}$} \\
\hline & & \multicolumn{2}{|c|}{ AAS (n=5) } & \multicolumn{2}{|c|}{ Proposed method $(n=5)$} & \\
\hline & & Found & RSD, \% & Found & RSD $^{\text {b }, ~ \% ~}$ & \\
\hline \multirow[t]{2}{*}{1} & Blood & 2.0 & 1.0 & 2.10 & 1.0 & Kidney diseases patient (Female) \\
\hline & Urine & 0.51 & 1.2 & 0.55 & 1.3 & \\
\hline \multirow[t]{2}{*}{2} & Blood & 0.65 & 1.5 & 0.70 & 1.5 & Anemia patient (Female) \\
\hline & Urine & 0.17 & 1.7 & 0.18 & 1.8 & \\
\hline \multirow[t]{2}{*}{3} & Blood & 1.0 & 1.3 & 1.05 & 1.3 & Pregnant women \\
\hline & Urine & 0.25 & 1.5 & 0.27 & 1.6 & \\
\hline \multirow[t]{2}{*}{4} & Blood & 4.95 & 1.0 & 4.85 & 1.2 & Liver cirrhosis patient (Male) \\
\hline & Urine & 1.25 & 1.5 & 1.21 & 1.8 & \\
\hline \multirow[t]{2}{*}{5} & Blood & 1.25 & 1.0 & 1.29 & 1.2 & Normal (Male) \\
\hline & Urine & 0.30 & 1.8 & 0.33 & 1.5 & \\
\hline
\end{tabular}

a The samples were from Chittagong Medical College Hospital, Chittagong.

${ }^{\mathrm{b}}$ The measure of precision is the relative standard deviation(RSD).

Table 8. Determination of iron in some surface soil samples.

\begin{tabular}{|c|c|c|}
\hline Serial no & Iron (mg/kg) a & Sample source c \\
\hline$\overline{S_{1}}$ & $21.0 \pm 1.5^{b}$ & $\begin{array}{l}\text { Marine soil } \\
\text { (Bay of Bengal, Chittagong, Bangladesh) }\end{array}$ \\
\hline $\mathrm{S}_{2}$ & $41.5 \pm 1.2$ & $\begin{array}{l}\text { Traffic soil } \\
\text { (Bahaddarhat, Bus Terminal, Chittgong) }\end{array}$ \\
\hline $\mathrm{S}_{3}$ & $34.5 \pm 1.4$ & $\begin{array}{l}\text { Estuarine soil } \\
\text { (Junction of Bay of Bengal and River Karnafuly, Chittagong, Bangladesh) }\end{array}$ \\
\hline $\mathrm{S}_{4}$ & $38.5 \pm 1.0$ & $\begin{array}{l}\text { Agricultural soil } \\
\text { (Chittagong University Campus) }\end{array}$ \\
\hline $\mathrm{S}_{5}$ & $78.8 \pm 2.0$ & $\begin{array}{l}\text { Industrial soil } \\
\text { (Bangladesh Steel Re-rolling Mills Ltd., Chittagong, Bangladesh) }\end{array}$ \\
\hline
\end{tabular}

a Average of five analysis of each sample.

${ }^{\mathrm{b}}$ The measure of precision is the standard deviation $( \pm \mathrm{s})$.

c Composition of soil samples: $\mathrm{C}, \mathrm{N}, \mathrm{P}, \mathrm{K}, \mathrm{Na}, \mathrm{Ca}, \mathrm{Mg}, \mathrm{Fe}, \mathrm{Pb}, \mathrm{Cu}, \mathrm{Zn}, \mathrm{Mn}, \mathrm{Mo}, \mathrm{Co}, \mathrm{NO}_{3}, \mathrm{NO}_{2}, \mathrm{SO}_{4}$, etc.

Table 9. Determination of iron in some food samples.

\begin{tabular}{|c|c|c|c|}
\hline \multirow[t]{2}{*}{ Serial no } & \multirow[t]{2}{*}{ Sample } & \multirow{2}{*}{$\begin{array}{l}\text { Iron }(\mathrm{mg} / \mathrm{kg} \text { or } \mathrm{mg} / \mathrm{L} \text { ) } \\
\text { Found }{ }^{ \pm} \mathrm{s}\end{array}$} & \multirow[t]{2}{*}{ Sample source } \\
\hline & & & \\
\hline 1 & $\begin{array}{l}\text { Cow's milk }{ }^{\mathrm{b}} \\
\text { (Boss indicus) }\end{array}$ & $2.0 \pm 1.5$ & Chittagong Market \\
\hline 2 & $\begin{array}{l}\text { Banana } \\
\text { (Musa acuminata) }\end{array}$ & $10.0 \pm 2.0$ & Chittagong Market \\
\hline 3 & $\begin{array}{l}\text { Tomato } \\
\text { (Licopersicon esculentum) }\end{array}$ & $18.0 \pm 1.0$ & Chittagong Market \\
\hline 4 & $\begin{array}{l}\text { Date juice } \mathrm{b} \\
\text { (Phoenix dactylifera) }\end{array}$ & $9.0 \pm 1.8$ & Chittagong Market \\
\hline 5 & $\begin{array}{l}\text { Arum } \\
\text { (Arum discorides) }\end{array}$ & $14.0 \pm 1.4$ & Chittagong Market \\
\hline 6 & $\begin{array}{l}\text { Guava } \\
\text { (Psidium guajava) }\end{array}$ & $12.0 \pm 1.3$ & Chittagong Market \\
\hline 7 & $\begin{array}{l}\text { Egg(Hen) } \\
\text { (Gallious domesticus) }\end{array}$ & $0.06 \pm 1.6$ & Chittagong Market \\
\hline
\end{tabular}

a Average of the five replicate determinations of each sample.

bValues in $\mathrm{mg} / \mathrm{L}$.

Table 10. Determination of iron in some pharmaceutical samples.

\begin{tabular}{|c|c|c|c|c|c|}
\hline \multirow[t]{2}{*}{ Serial no } & \multirow[t]{2}{*}{ Compositionof Tablet } & \multirow[t]{2}{*}{ Trade name } & \multicolumn{2}{|c|}{ Iron $(\mu \mathrm{g} / \mathrm{g}$ or $\mu \mathrm{g} / \mathrm{mL})$} & \multirow[t]{2}{*}{ RSD, \% } \\
\hline & & & Reported & Found & \\
\hline 1 & Ferrous sulphate $(150 \mathrm{mg} \text { per } 0.45 \mathrm{~g})^{a}$ & $\begin{array}{l}\text { Zif } \\
\text { (Square Pharmaceuticals Ltd.) }\end{array}$ & 33.34 & 338.0 & 2.0 \\
\hline 2 & Iron(III)hydroxide $(10 \mathrm{mg} / \mathrm{mL})^{b}$ & $\begin{array}{l}\text { Aritone ZI } \\
\text { (Incepta Pharmaceuticals Ltd.) }\end{array}$ & 10,000 & 10,050 & 1.5 \\
\hline 3 & Carbonyl Iron (51 mg per $0.45 \mathrm{~g}$ ) a & $\begin{array}{l}\text { Glory } \\
\text { (Orion Pharma Ltd.) }\end{array}$ & 113.34 & 115.0 & 2.5 \\
\hline
\end{tabular}

a Values in $\mu \mathrm{g} / \mathrm{g}$.

b Values in $\mu \mathrm{g} / \mathrm{mL}$.

\subsubsection{Determination of iron in synthetic mixtures}

Several synthetic mixtures of varying compositions containing iron and diverse ions of known concentrations were determined by the present method and the results were found to be highly reproducible. The results are shown in Table 4. Accurate recoveries were achieved in all solutions.

\subsubsection{Determination of iron in brass, alloys and steels (Certified reference materials)}

A $0.1 \mathrm{~g}$ amount of a brass or alloy or steel sample containing $0.43-34.26 \%$ of iron was weighed accurately and placed in a $50 \mathrm{~mL}$ erlenmeyer flask following a method recommended by Parker [27]. To it, $10 \mathrm{~mL}$ of concentrated $\mathrm{HNO}_{3}, 1 \mathrm{~mL}$ of concentrated $\mathrm{H}_{2} \mathrm{SO}_{4}$ and $1-2 \mathrm{~mL}$ of $1 \% \mathrm{KMnO}_{4}$ were added to oxidize $\mathrm{Fe}(\mathrm{II})$ to $\mathrm{Fe}(\mathrm{III})$, excess of $\mathrm{KMnO}_{4}$ was removed by addition of $1-2 \mathrm{~mL}$ of freshly prepared $2.5 \%$ sodium azide solution and carefully covering the flask with a watch glass until the brisk reaction subsided. The solution was heated to drive off excess azide solution and simmered gently after the addition of $5 \mathrm{~mL}$ of concentrated $\mathrm{HNO}_{3}$ until all carbides were decomposed. The solution was carefully evaporated to dense white fumes to drive off the oxides of nitrogen and then cooled to room temperature $\left(25 \pm 5^{\circ} \mathrm{C}\right)$. 
Table 11. Determination of iron(II) and iron(III) in mixtures.

\begin{tabular}{|c|c|c|c|c|c|c|c|}
\hline \multirow[t]{2}{*}{ Serial no } & \multirow[t]{2}{*}{$\mathrm{Fe}(\mathrm{III}): \mathrm{Fe}(\mathrm{II})$} & \multicolumn{2}{|c|}{$\begin{array}{l}\text { Fe, taken } \\
\text { (mg/L) }\end{array}$} & \multicolumn{2}{|c|}{$\begin{array}{l}\text { Fe, found } \\
\text { (mg/L) }\end{array}$} & \multicolumn{2}{|l|}{ Error } \\
\hline & & $\mathrm{Fe}(\mathrm{III})$ & $\mathrm{Fe}(\mathrm{II})$ & $\mathrm{Fe}($ III) & $\mathrm{Fe}(\mathrm{II})$ & $\mathrm{Fe}(\mathrm{III})$ & $\mathrm{Fe}(\mathrm{II})$ \\
\hline 1 & $1: 1$ & 1.00 & 1.00 & 0.99 & 0.98 & 0.01 & 0.02 \\
\hline 2 & $1: 1$ & 1.00 & 1.00 & 1.00 & 1.00 & 0.00 & 0.00 \\
\hline 3 & $1: 1$ & 1.00 & 1.00 & 0.98 & 0.99 & 0.02 & 0.01 \\
\hline \multicolumn{8}{|c|}{ Mean error: $\mathrm{Fe}(\mathrm{III})= \pm 0.01 ; \mathrm{Fe}(\mathrm{II})= \pm 0.01$} \\
\hline$\overline{1}$ & $1: 3$ & 1.00 & 3.00 & 0.98 & 2.98 & 0.02 & 0.02 \\
\hline 2 & $1: 3$ & 1.00 & 3.00 & 0.98 & 2.99 & 0.02 & 0.01 \\
\hline 3 & $1: 3$ & 1.00 & 3.00 & 0.99 & 2.98 & 0.01 & 0.02 \\
\hline \multirow{2}{*}{\multicolumn{8}{|c|}{$\begin{array}{l}\text { Mean error: } \mathrm{Fe}(\mathrm{III})= \pm 0.016 ; \mathrm{Fe}(\mathrm{II})= \pm 0.016 \\
\text { Standard deviation: } \mathrm{Fe}(\mathrm{III})= \pm 0.0058 ; \mathrm{Fe}(\mathrm{II})= \pm 0.006\end{array}$}} \\
\hline & & & & & & & \\
\hline$\overline{1}$ & $1: 5$ & 1.00 & 5.00 & 0.99 & 4.98 & 0.01 & 0.02 \\
\hline 2 & $1: 5$ & 1.00 & 5.00 & 1.00 & 4.99 & 0.00 & 0.01 \\
\hline 3 & $1: 5$ & 1.00 & 5.00 & 0.98 & 4.98 & 0.02 & 0.02 \\
\hline \multicolumn{8}{|c|}{ Mean error: $\mathrm{Fe}(\mathrm{III})= \pm 0.01 ; \mathrm{Fe}(\mathrm{II})= \pm 0.016$} \\
\hline
\end{tabular}

After suitable dilution with deionized water, the contents of the Erlenmeyer flask were warmed to dissolve the soluble salts. The solution was then cooled and neutralized with a dilute $\mathrm{NH}_{4} \mathrm{OH}$ solution. The resulting solution was filtered, if necessary, through a Whatman No. 40 filter paper into a $25 \mathrm{~mL}$ calibrated flask. The residue was washed with a small volume of hot $(1+99) \mathrm{H}_{2} \mathrm{SO}_{4}$, followed by water and the volume was made up to the mark with deionized water.

A suitable aliquot (1-2 $\mathrm{mL}$ ) of the above solution was taken into a $10 \mathrm{~mL}$ calibrated flask and the iron content was determined as described under procedure. Based on five replicate analyses, average iron concentration determined by spectrophotometric method was in close agreement with the certified values (Table 5). The results are shown in Table 5.

\subsubsection{Determination of iron in environmental waters}

Each filtered (with Whatman No. 40) environmental water sample $(1000 \mathrm{~mL})$ evaporated nearly to dryness with a mixture of $3 \mathrm{~mL}$ concentrated $\mathrm{H}_{2} \mathrm{SO}_{4}$ and $10 \mathrm{~mL}$ of concentrated $\mathrm{HNO}_{3}$ in a fume cupboard and 1-2 $\mathrm{mL}$ of $\mathrm{KMnO}_{4}$, following a method recommended by Greenberg et al. [28]. Excess of $\mathrm{KMnO}_{4}$ was removed by $2.5 \%$ freshly prepared sodium azide solution and was heated with $10 \mathrm{~mL}$ of deionized water in order to remove excess azide solution and dissolves the salts. The solution was then cooled and neutralized with dilute $\mathrm{NH}_{4} \mathrm{OH}$ solution. The resulting solution was then filtered (if necessary) and quantitatively transferred into a $25 \mathrm{~mL}$ calibrated flask and made up to the mark with deionized water.

An aliquot (1-2 $\mathrm{mL}$ ) of this pre-concentrated water sample was pipetted into a $10 \mathrm{~mL}$ calibrated flask and the iron content was determined as described under the procedure. The analyses of environmental water samples for iron from various sources are shown in Table 6.

Most spectrophotometric method for the determination of iron in natural and sea-water require pre-concentration of iron [28]. The concentration of iron in natural and sea-water is a few $\mu \mathrm{g} / \mathrm{L}$ in Japan [29]. The mean concentration of iron found in UK drinking water is less than $1 \mathrm{mg} / \mathrm{L}$ (Average: $200 \mu \mathrm{g} / \mathrm{L}$ ) [30].

\subsubsection{Determination of iron in biological samples}

Human blood (2-5 mL) and urine (20-30 mL) was collected in polyethane bottles from the affected persons. Immediately after collection, they were stored in a salt-ice mixture and later, at the laboratory, were kept at $-20^{\circ} \mathrm{C}$. The samples were taken into a $100 \mathrm{~mL}$ micro-Kjeldahl flask. Glass bead and $10 \mathrm{~mL}$ of concentrated nitric acid were added and the flask was placed on the digester under gentle heating. When the initial brisk reaction was over, the solution was removed and cooled following a method recommended by Stahr [31]. $1 \mathrm{~mL}$ volume of concentrated sulfuric acid and $1-2 \mathrm{~mL}$ of $1 \% \mathrm{KMnO}_{4}$ were added carefully and excess of $\mathrm{KMnO}_{4}$ was removed by $2.5 \%$ freshly prepared sodium azide solution followed by the addition of $0.5 \mathrm{~mL}$ of $70 \% \mathrm{HClO}_{4}$ and heating was continued for at least $1 / 2 \mathrm{hr}$ to remove excess azide solution and then cooled. The solution of flask then neutralized with dilute $\mathrm{NH}_{4} \mathrm{OH}$ solution. The resultant solution was then transferred quantitatively into a $10 \mathrm{~mL}$ calibrated flask and made up to the mark with deionized water.

A suitable aliquot (1-2 mL) of the final solution was pipetted into a $10 \mathrm{~mL}$ calibrated flask and the iron content was determined as described under the general procedure. The results of biological analyses by the spectrophotometric method were found to be in excellent agreement with those obtained by AAS. The results are shown in Table 7.

The abnormally high value for the liver cirrhosis patient is probably due to the involvement of high iron concentration with $\mathrm{Cu}$ and $\mathrm{Zn}$. Occurrence of such high iron contents are also reported in liver cirrhosis patients from some developed countries [7].

\subsubsection{Determination of iron in soil samples}

An air dried homogenized soil sample $(100 \mathrm{~g})$ was weighed accurately and placed in a $100 \mathrm{~mL}$ micro-Kjeldahl flask. The sample was digested in the presence of a oxidizing agen $(1 \%$ $\mathrm{KMnO}_{4}$ ), following the method recommended by Hesse [32] Excess of $\mathrm{KMnO}_{4}$ was removed by $2.5 \%$ freshly prepared sodium azide solution and heating was continued for at least $1 / 2$ $\mathrm{hr}$ to remove excess azide solution and then cooled. The content of the flask was filtered through a Whatman No. 40 filter paper into a $25 \mathrm{~mL}$ calibrated flask and neutralized with dilute $\mathrm{NH}_{4} \mathrm{OH}$ solution. Then the solution of the flask was made up to the mark with deionized water.

Suitable aliquots $(1-2 \mathrm{~mL})$ were transferred into a $10 \mathrm{~mL}$ calibrated flask and a calculated amount of $1 \times 10^{-4} \mathrm{~mol} / \mathrm{L} \mathrm{H}_{2} \mathrm{SO}_{4}$ needed to give a final acidity of $2 \times 10^{-6}-2 \times 10^{-5} \mathrm{~mol} / \mathrm{L} \mathrm{H}_{2} \mathrm{SO}_{4}$ was added. The iron content was then determined by the above procedure and quantified from a calibration graph prepared concurrently. The results are shown in Table 8.

\subsubsection{Determination of iron in food samples}

An air dried food sample Banana $(50 \mathrm{~g})$, tomato $(50 \mathrm{~g})$, aruma (50 g), Guava (50 g), egg (1 piece) and Cow's milk (100 $\mathrm{mL})$, Date juice $(100 \mathrm{~mL})$ were taken in a $100 \mathrm{~mL}$ microKjeldahl flask. A glass bead and $10 \mathrm{~mL}$ of concentrated nitric acid were added and the flask was placed on the digester under gentle heating. When the initial brisk reaction was over, the solution was removed and cooled following a method 
recommended by Stahr [31]. $1 \mathrm{~mL}$ volume of concentrated sulfuric acid and $1-2 \mathrm{~mL}$ of $1 \% \mathrm{KMnO}_{4}$ were added carefully and excess of $\mathrm{KMnO}_{4}$ was removed by $2.5 \%$ freshly prepared sodium azide solution followed by the addition of $0.5 \mathrm{~mL}$ of $70 \% \mathrm{HClO}_{4}$ and heating was continued for at least $1 / 2 \mathrm{hr}$ to remove excess azide solution and then cooled. The resultant solution was then transferred quantitatively into a $50 \mathrm{~mL}$ calibrated flask and made up to the mark with deionized water.

A suitable aliquot (1-2 mL) of the final solution was pipetted into a $10 \mathrm{~mL}$ calibrated flask and the iron content was determined as described under the procedure. High value of iron for tomato is probably due to the involvement of high iron concentration in the soil. The results are shown in Table 9.

\subsubsection{Determination of iron in some pharmaceutical samples}

Finished pharmaceutical samples (Iron containing tablet and syrap) were quantitatively taken in a beaker. Added $10 \mathrm{~mL}$ of conc. nitric acid and heated to dryness and then added $10 \mathrm{~mL}$ of $20 \%(v: v)$ of sulfuric acid and 1-2 drops of perchloric acid. The volume was reduced to $2-5 \mathrm{~mL}$ and then cooled to room temperature. The solution was then neutralized with dilute $\mathrm{NH}_{4} \mathrm{OH}$ in the presence of a $1-2 \mathrm{~mL} 0.1 \%$ (w:v) $\mathrm{KMnO}_{4}$ solution to oxidize $\mathrm{Fe}(\mathrm{II})$ to $\mathrm{Fe}(\mathrm{III})$ and excess of $\mathrm{KMnO}_{4}$ was removed by $2.5 \%$ freshly prepared sodium azide solution. The resulting solution was then filtered and quantitatively transferred into a $25 \mathrm{~mL}$ volumetric flask and made up to the mark with deionized water.

A suitable aliquot (1-2 mL) of the final solution was pipetted into a $10 \mathrm{~mL}$ calibrated flask and the iron content was determined as described under the procedure. High value of iron for tomato is probably due to the involvement of high iron concentration in the soil. The results are shown in Table 10.

\subsubsection{Determination of iron (II) and iron (III) in mixtures}

Suitable aliquots (1-2 mL) of iron(III + II) mixtures (preferably 1:1, 1:3, 1:5) were taken in a $25 \mathrm{~mL}$ conical flask. A few drops of $0.05 \mathrm{~mol} / \mathrm{L}$ sulfuric acid and 1-3 mL of $1 \%(w: v)$ potassium permanganate solution were added to oxidize iron(II). A $5 \mathrm{~mL}$ volume of water was added to the mixtures, which were then heated on a steam bath for 10-15 min, with occasional gentle shaking, and then cooled to room temperature. Then, 3-4 drops of a freshly prepared sodium azide solution $\left(2.5 \%\right.$ w:v) was added to remove excess $\mathrm{KMnO}_{4}$ and heated gently with the further addition of $2-3 \mathrm{~mL}$ of water, if necessary, for $5 \mathrm{~min}$ to drive off the excess azide solution and cooled to room temperature. The reaction mixture was neutralized with dilute $\mathrm{NH}_{4} \mathrm{OH}$ and transferred quantitatively into a $10 \mathrm{~mL}$ volumetric flask. Then the total iron(III+II) content was determined according to the general procedure with the help of the calibration graph.

An equal aliquot of the above iron(III + II) mixture was taken into a $25 \mathrm{~mL}$ beaker. One $\mathrm{ml}$ of $0.01 \%(w: v) 1,10$ phenanthroline was added to mask iron(II) and neutralize with dilute $\mathrm{NH}_{4} \mathrm{OH}$. After, the content of the beaker was transferred into a $10 \mathrm{ml}$ volumetric flask and its iron (III) content was determined according to the general procedure. The iron concentration was calculated in $\mathrm{mg} / \mathrm{L}$ or $\mu \mathrm{g} / \mathrm{L}$ with the aid of a calibration graph. This gives a measure of iron originally present as iron(III) in the mixture. The value of the iron (II) concentration was calculated by subtracting the concentration of iron(III) from the corresponding total iron concentration. The results were found to be highly reproducible. The results of a set of determination are given in Table 11.

\section{Conclusions}

In the present work, a new, simple, sensitive, selective and inexpensive spectrophotometric method with the Fe(III)-tiron complex was developed for the determination of iron in real, environmental, biological, pharmaceutical, food and soil samples for continuous monitoring to establish the trace levels of iron in different sample matrices. The similar new, sensitive and selective methods [33-39] were reported by the author.

Compared with the other methods in the literature [13-18] the proposed method has several remarkable analytical characteristics:

i) This method was developed in completely aqueous media, so toxic and carcinogenic organic solvents were totally avoided.

ii) The proposed method is highly sensitive with molar absorptivity of the complex of $6 \times 10^{5} \mathrm{~L} / \mathrm{mol} . \mathrm{cm}$. Thus amount of ng/g of iron can be determined without pre-concentration.

iii) The proposed method is very simple, rapid and stable. The reaction of iron(III)with tiron is completed rapidly in aqueous medium within $1 \mathrm{~min}$ at room temperature and offer the advantage of high complex stability $(24 \mathrm{~h})$.

iv) The method has added advantages of determining individual amounts of Fe(III) and Fe(II).

v) With suitable masking agents, the reaction can be made highly selective.

The proposed method using tiron in aqueous solution not only is one of the most sensitive methods for the trace determination of iron but also is excellent in terms of sensitivity and simplicity. Therefore, this method will be successfully applied to the monitoring of trace amounts of iron in real, environmental, industrial effluents, biological, food, pharmaceutical and soil samples.

\section{Acknowledgements}

We are highly grateful to the authorities of Chittagong Medical College Hospital for supplying Biological samples.

\section{References}

[1]. Barceloux, D. G. J. Clin. Toxicol. 1999, 37(2), 173-194

[2]. Clayton, G. D.; Clayton, F. E. (eds.) Pathy's Industrial Hygiene and Toxicology, $3^{\text {rd }}$ edition, Wiley, New York, 1981, pp. 1658.

[3]. Herney, L. H. Trace Element Analytical Chemistry in Medicine and Biology, Pratter P. and Scharmel, P. (eds.), Vol. 3, Walter de Gruyter, Berlin, 1984, pp. 375

[4]. Goyter, R. A.; Clarkson, T. W. Casarette and Doull's Toxicology: The Basic Science of Poisons, C. D. Klaassen (ed.), $6^{\text {th }}$ edition, Macmillan Publishing Company, 2001, pp. 827.

[5]. Beecks, L. R. Anal. Chem. 1986, 58(9), 975A-978A

[6]. Key, M. M.; Henschel, A. F.; Butter, J.; Ligo, R. N.; Tebershed, I. R. Occupational Diseases : A Guide to their recognition, US Department of Health, Education and Welfare, U. S. Govt. Printing, Washington, D. C. 1977.

[7]. Venugopal, B.; Luckey, T. D. Metal Toxicity in Mammals-2, Plenum Press, New York, 1979, pp. 275.

[8]. Clayton, G. D.; Clayton, F. E. (eds.), Patty's Industrial Hygiene and Toxicology, Wiley, New York, Vol. 2, 3rd edition, 1981, pp. 1662.

[9]. Institute of Medicine, Food and Nutrition Board, Dietary Reference Intakes for vit. A, vit. K, Arsenic, Chromium, Copper, Iodine, Iron, Manganese, Molybdenum, Nickel, Silicon, Vanadium and Zinc, Washington National Academy Press, 2001.

[10]. Dallman, P. R. Annu. Rev. Nutr. 1986, 6, 13-40.

[11]. Andrews, N. C. New Engl. J. Med. 1999, 341(26), 1986-1995.

[12]. Corbett, J. V. MCN Am. J. Matern. Child. Nurs. 1995, 20(4), 234-239

[13]. Abdollahia, H.; Shariat, P. M.; Khoshayand, M. R. Iranian J. Pharm. Res. 2003, 2(4), 207-212.

[14]. Jankiewicz, B.; Ptaszynsky, B.; Turek A. Pol. J. Environ. Stud. 2002, 11(6), 745-749.

[15]. Malik, A. K.; Bansal, S.; Aluakh, J. S. Anal. Bioanal. Chem. 2003, 375(8), 1250-1253.

[16]. Chen, Y.; Ding, C. M.; Zhou, T. Z.; Qi, D. Y. Fresen. J. Anal. Chem. 1999, 363(1), 119-120.

[17]. Demirhan, N.; Elmali, F. T. Turk. J. Chem. 2003, 27(3), 315-322.

[18]. Stalikas, C. D.; Pappas, A. C.; Karayannis, M. I.; Veltsistas, P. G. Microchim. Acta 2003, 142(1-2), 43-48.

[19]. Vogel, A. I. Quantitative Inorganic Analysis, $3^{\text {rd }}$ edition, The English Language Book of Society and Longman, London, 1961, pp. 309. 
[20]. Mukharjee, A. K. Analytical Chemistry of Zirconium and Hafnium, $1^{\text {st }}$ edition, Pergamon Press, New York, 1970, pp. 385.

[21]. Pal, B. K.; Chowdhury, B. Microchim. Acta 1984, 83(1-2) 121-131.

[22]. Busev, A. I.; Tiptsova, V. G.; Ivanov, V. M. (eds.), Analytical Chemistry of Rare Elements, Mir Publishers, Moscow, 1981. pp. 386.

[23]. Sandell, E. B. Colorimetric Determination of Traces of Metals, $3^{\text {rd }}$ edition, InterScience, New York, 1965, pp. 269.

[24]. Ojeda, C. B.; Torres, A. G. Rojas, F. S.; Pavon, J. M. C. Analyst 1987, 112, 1499-1502.

[25]. Job, P. Anm. Chim. (Paris) 1928, 9, 113-116.

[26]. You, J. A.; Jones, A. L. Ind. Eng. Chem. Anal. Ed. 1944, 16, 11-16.

[27]. Parker, G. A. Analytical Chemistry of Molybdenum, Springer Verlag Berlin, 1983.

[28]. Greenberg, A. E.; Clesceri, L. S.; Trussell, R. R. (eds.), Standard Methods for the Examination of Water and Waste Water, $18^{\text {th }}$ edition, American Public Health Association, Washington DC. 1992. pp. 3-53.

[29]. Ali, A. M.; Mori, Y.; Sawada, K. Anal. Sci. 2006, 22(9), 1169-1172.

[30]. Fifield, F. W.; Haines, P. J. (Eds.), Environmental Chemistry, 2nd edition, Blackwell Science, London, 2000, pp. 420.

[31]. Stahr, H. M. Analytical Methods in Toxicology, $3^{\text {rdedition, John Wiley }}$ and Sons, New York, 1991, pp. 75.

[32]. Hesse, P. R. A. Text Book of Soil Chemical Analysis, Chemical Publishing Co. Inc. New York, 1972, pp. 332.

[33]. Ahmed, M. J.; Roy, U. K. Turk. J. Chem. 2009, 33, 709-726.

[34]. Ahmed, M. J.; Mamun M. A. Talanta 2001, 55(1), 43-55.

[35]. Ahmed, M. J.; Hoque, M. R.; Khan A. S. M. S. H.; Bhattacharjee, S. C. Eurasian J. Anal. Chem. 2010, 5(1), 1-15.

[36]. Ahmed, M. J.; Hossan, K. J. J. Iran. Chem. Soc. 2008, 5(4), 677-688

[37]. Ahmed, M. J.; Tasnima, Z. Pakistan J. Anal. Environ. Chem. 2012, 13(1), 22-35.

[38]. Ahmed, M. J.; Zannat, T.; Saifuddin, M.; Bhattacharjee, S. C. The Global Directory for Environmental Technology (Green Pages) 2010, URL: http://www.eco-web.com/edi/100412.html, ID:100412.

[39]. Soomro, R.; Ahmed, M. J.; Najma, M. Turk. J. Chem. 2011, 35(11), 155170 